CONFERENCIAS E DISCURSOS.

\title{
Discurso pronunciado no Tribunal de Alçada, na Guanabara, ao receber a cruz do mérito judiciário, no dia da justiça.
}

\author{
Candido Mota Fitho \\ Ministro do Supremo Tribunal Federal - \\ Professor Catedrático de Direito Constitucional \\ na Faculdade de Direito da Universidade de \\ São Paulo.
}

"Senhores Magistrados.

Para nós, juízes, que não temos as facilidades do poder, nem as consagrações dos vitoriosos, que vivemos no consôlo do dever cumprido, - êste prêmio, vindo de onde vem, é o que, sem vaidade, poderíamos desejar. Ao recebê-lo, no dia de hoje, que relembra que a história da civilização não é mais do que a história da Justiça, - procuramos, no calor destas palavras e nos compromissos que elas reafirmam, traduzir os nossos agradecimentos.

Esta solenidade, meus Senhores, se realiza num instante grave da vida brasileira, quando uma revolução vitoriosa se propõe a reparar os males do desregramento e da subversão, que vêm consumindo as energias do País. Como foi feita e para o que foi feita, ela procurou ser, de comêço, discreta na carga de medidas radicais, como também se auto-limitou, pondo a salvo o sistema de garantias juridicas consubstanciadas na Constituição e nas leis.

Com isso, a Justiça continuou a sua tarefa, na salvaguarda dos diretos em conflito e da ordem democrática constituída. 
Viram muitos, nessa confraternização do movimento revolucionário com a legalidade um contrasenso, porque as revoluções, por índole, falam a linguagem da violência, enquanto que as leis falam a linguagem do direito e da ordem. $\mathrm{E}$, daí, a pergunta, que assume entonação pungente: Como pode um movimento destinado a afastar certos males, encrustrados de há muito, no maquinário do Estado, embaraçar-se sob a pressão de velhos compromissos legais?

Mas, esta pergunta, que agora se faz neste recinto, não é de hoje e vem sendo formulada nas ocorrências do mundo atual, porque vivemos uma época de problemas surpreendentes, que é a época das revoluções.

$\mathrm{Na}$ Europa, velha de guerra, vítima maior de duas conflagrações de caráter mundial, as revoluções vem fornecendo à Sociologia Política, à Teoria Geral do Estado, à Ciência e à Filosofia do Direito, êsse tema emocionante, porque as revoluções, por mais radicais que se mostrem, como a Revolução Francesa e a Revolução Russa, não puderam, de pronto, abandonar as leis existentes, naquilo que elas auxiliariam a consagração da ordem possível ou de um mínimo de ordem.

E que a revolução verdadeira, aquela como a concebe Ortega y Gasset, que prefere atacar os usos mais do que os abusos, não pode negar a existência de direito, garantido pela lei, mesmo porque, na sua ruptura com o coexistente, a revolução é uma forma de reclamar direitos e lutar por êles.

Os juizes, que são a boca da lei, que não participam, por dever de ofício, de qualquer atividade política, não podem dizer dos rumos revolucionários, mas podem dizer, sem qualquer constrangimento, que descobrem nessa aproximação entre a revolução e a legalidade, o caminho mais seguro para a convivência social.

Renan, que estudou as revoluções italianas, revela que elas alcançaram até seu tempo, ao número de sete mil e duzentas, com mais de setecentos massacres, sem que, com 
tudo isso, a tradição ficasse morta. (Les révolutions d'Italie).

No século vinte porém, - testemunhamos nós, - a Itália viu-se assaltada pelo fascismo, por invasões estrangeiras e, afinal, conquistada pela República. Sofreu, por isso mesmo, as dificuldades de manter certa legalidade em meio das atribulações revolucionárias. Enquanto o fascismo mantinha a Constituição e numerosas leis do regime deposto, a República, que justificava seu horror ao fascismo, mantinha, apesar disso, muitas leis do regime fascista.

Há, em conseqüência, numerosa literatura sob êsse desconfiado diálogo entre a legalidade e a revolução, realçando-se o estudo do mestre Sílvio Tosi ( $A$ revolução $e$ a ordem jurídica), que mostra, à luz meridiana, que a afirmativa marxista, que considera como fetichismo burguês, o culto da legalidade, - é, històricamente, vasia de sentido, porque, para êle, não há uma só crise revolucionária, nem mesmo a russa de 1917, que tenha, radicalmente, negado a continuidade do direito legalmente constituído, principalmente enquanto o direito novo, não está em condições de substituir o antigo.

Aliás, Del Vecchio, com abundância de argumentos, estuda o problema das leis nos períodos revolucionários e, depois de acentuar que existem sempre motivos para impugnar-se a ordem jurídica, ou pela aspiração de uma justiça mais perfeita ou pela ânsia egoista de subtração aos deveres que ela impõe, - escreve: - "Quem aspira simplesmente, sacudir de si o pêso dos deveres impostos pela ordenação jurídica estatuída, não pode dizer que luta pela Justiça. Nada se deve pretender em nome da Justiça sem que haja sujeição ao vínculo por ela impôsto e que é a correção radical do egoismo". (A Justiça)

Na França, atormentada, ainda mais, depois da última guerra, se viu envolvida pelo mesmo problema, quando o ódio e o mêdo criavam por tôda parte, "o complexo da traição". É o que mostra Frederic JafFrée, no exame do papel da Justiça na climática revolucionária, em seu ensaio 
sôbre os tribunais de excepção, quando não vascila em descer ao processo do General Salan e dos membros da o.A.s., para acentuar a impossibilidade de estinguir-se, mesmo nos momentos extraordinários, a justiça ordinária. E o respeitável Ripert, em seu livro sôbre as fôrças criadoras do direito, ao lembrar a serpente de Paul Valery, diz que a revolução só se impõe à sensibilidade popular, quando procura manter um sistema de garantias juridicas. E conclui: - "Toute révolution est à la fois une rupture avec la tradiction et la utilization de cette tradiction".

O mesmo aconteceu na Espanha, que teve, no passado, sua época de "pronunciamientos". Na tragédia impetuosa da última guerra civil, os excessos foram atenuados pelas leis que conseguiam sobreviver. O próprio Salvador MadaRIAGA, incorrigivel liberal, escreveu no exílio: - "Os tribunais, que se sentem vigiados, é que fazem que todos saiam ganhando..." (De la angustia a la libertad).

Por fim, a Alemanha, derrotada na primeira guerra, tomada pelo grupo social democrata e por Hitler, invadida por fim, após a segunda derrota, dá ampla margem para que os juristas enfrentem o tema, que entra em fase polêmica a partir das posições assumidas pelo positivismo kelseneano. Heinrich Herrfahrdt escreve um livro sôbre a Revolução e a ciência do direito, no qual procura resumir os debates travados. Para êle, a modificação violenta dos fundamentos jurídicos do Estado, não impede que o direito procure cumprir sua missão, mesmo que defronte com o radicalismo dos Conselhos de trabalhadores e soldados. Como Radbruch e Kelsen, êle procura então encarar de frente o problema da vigência. E estuda a delicada posição do juiz obrigado a restringir, exclusivamente, seu comportamento, aos pontos de vista jurídicos. Porém, faz ver que o juiz, que julga pelo direito, na severa obediência à lei, consegue se impor, mesmo deante das desconfianças e das objeções dos mais extremados, que proclamam que a justiça não ajuda os intuitos revolucionários. 
Como se vê, pela experiência histórica, pela própria realidade do conteúdo juridico e do papel, intransferivel, que êle exerce no plano da vitalidade social, a revolução, como fôrça política "extra legem" e "contra legem", tem sêde da lei, como a tem a sociedade normalmente constituida. A justiça "é então ordem social" como afirma Mircea DJuvara.

Mesmo, pelo fato da revolução trazer consigo um poder constituinte, isto não quer dizer que êsse poder, não se incline, no próprio interêsse revolucionário, por certas leis existentes. Eis porque, em 1789, insiste-se em conservar certos andaimes para que o edifício social, em obras, não soçobre. E podemos ler, em documento dessa época: -- "La Convention Nationale decrète que jusq'à ce qu'il en aient autrement ordonné, les lois non abrogées seront provisoirement executées; que les pouvoirs non révoqués ou non suspendus seront provisoirement mantenus; que les contribuitions publiques existantes continueront à l'être perçues et payées comme pour le passe". (Maurice Duverger, Collection des Lois et des Decrets, t. 5., p. 1).

Uma revolução, meus Senhores, que coloca o instrumento da legalidade para a consecução de seus fins, para revolver, como o arado, a terra para o plantio, pode ser mais trabalhosa, pode inquietar aos mais inquietos; é, contudo, mais firme na conclusão de suas vitórias.

No Brasil, a revolução da independência nacional, que se fêz sob as idéias libertadoras do século xviII, foi, desde logo, no vazio da Colônia, conduzida com o emprêgo das leis portuguêsas. Proclamada a República, que destruía uma forma de Estado e uma forma de govêrno, o nôvo regime não repudiou tôdas as leis monárquicas, senão as aproveitou para a eficácia da nova ordem. Por isso, os chefes civis e militares, de 1889 , viram, de pronto, a necessidade de manter certas leis, para que fôsse mantida a revolução.

É verdade que as revoluções levam, em seu impulso, entre seus apaniguados e heróis, os incoerentes, os intem- 
pestivos, os aventureiros, os insólitos, como aquêles que se assemelham a Gamelin de Les dieux ont soif, de Anatole France.

Mas, por isso mesmo, os juízes, não podem deixar de compreender aquilo que STHENDal denomina "o direito da realidade", isto é, o estado febril da sociedade, com o seu pulso irregular e apressado e verificar, assim, onde a lesão revolucionária resiste à cicatrização, onde ao direito é vedado a entrar e onde êle precisa entrar.

Não é a crise do direito que perturba o juiz, mas os fatos que se entrechocam e o perigo de ser sua missão explorada pelos manejadores de conflitos.

Mesmo, com êsses dados oferecidos por um momento contraditório, o juiz tem, como medida de suas decisões, os direitos fundamentais do homem, isto é, aquêles que resguardam sua liberdade e sua dignidade.

Com a mais segura convicção, êle repete com IHering que "o direito é a melhor política do poder". E se a revolução quer se definir pela verdade democrática e proclama ter por eixo a justiça, que podeis fazer mais senhores Juizes?

Podemos responder, sem vacilar: - Vamos aplicar o direito existente, enquanto existente; vamos fazer viver a lei enquanto a lei existir.

E isto, meus caros Colegas, o que antes fazíamos. que estamos fazendo agora, afastando de nós os interêsses que não sejam do povo e da Nação.

Assim, honramos as insignias que hoje recebemos, conservadas daqui por diante, pela intrepidez de nossas convicções, pela serenidade de nossas sentenças, pelo dever que temos de servir à Justiça para servir, com ela, aos direitos do povo brasileiro. 